
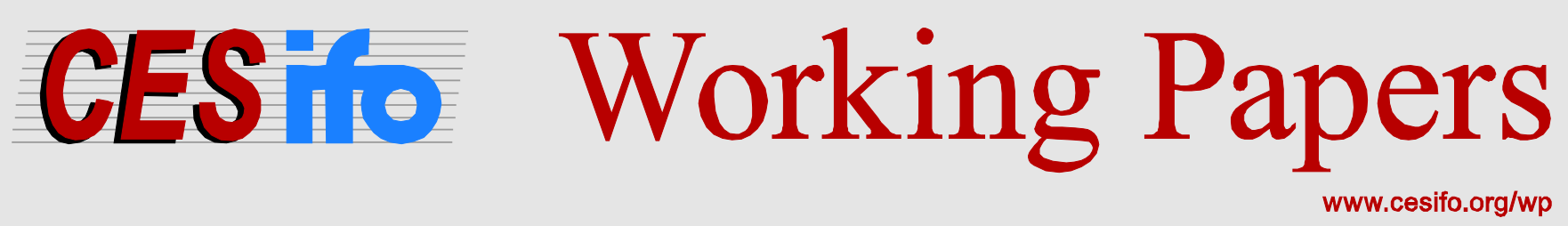

\title{
Using Military Build-Ups to Capture Fiscal Shocks: A Reassessment
}

\author{
Weonho Yang \\ Jan Fidrmuc \\ Sugata Ghosh
}

\author{
CESIFO WORKING PAPER NO. 4689 \\ CATEGORY 6: Fiscal Policy, MaCROECONOMICS AND GROWTH \\ MARCH 2014
}

An electronic version of the paper may be downloaded

- from the SSRN website:

- from the RePEc website:

- from the CESifo website:

WWW.SSRN.com

www.RePEc.org

www.CESifo-group.org/wp

\section{CESifo}




\title{
Using Military Build-Ups to Capture Fiscal Shocks: A Reassessment
}

\begin{abstract}
Ramey (2011a) and others argue that increases in government spending associated with wars and military build-ups constitute a good instrument for measuring the macroeconomic effects of fiscal shocks. We argue that this instrument has two important drawbacks: the composition of government spending during military build-ups in the US differs substantially from general government expenditure, and increases in military spending tend to crowd out federal nondefense spending as well as spending by state and local governments. These weaknesses help to explain why fiscal multipliers estimated with military build-ups tend to be smaller than those estimated using other approaches.
\end{abstract}

JEL-Code: E130, E220, E620.

Keywords: fiscal shocks, fiscal multiplier, military build-ups, US economy.

Weonho Yang

Ministry of Strategy and Finance

South Korea

\author{
Jan Fidrmuc* \\ Department of Economics and Finance \\ Brunel University \\ United Kingdom - Uxbridge, UB8 3PH \\ Jan.Fidrmuc@brunel.ac.uk \\ jan@fidrmuc.net
}

\author{
Sugata Ghosh \\ Department of Economics and Finance \\ CEDI \& BMRC \\ Brunel University / United Kingdom \\ sugata.ghosh@brunel.ac.uk
}

*corresponding author

February 2014 


\section{Introduction}

In the wake of the recent financial crisis, the role and effectiveness of fiscal policy remains a topical yet controversial issue: some governments have increased their spending to stimulate economic growth, while others, riddled with debt problems, were forced to cut theirs sharply. This makes capturing the effects of fiscal policy an important and highly policy-relevant exercise. This task is made especially challenging by the fact that neoclassical and new Keynesian theories make rather different predictions regarding the effects of fiscal policy.

Although most studies agree that fiscal policy stimulates output in the short-run, there is considerable disagreement regarding the size and the transmission of its effects on economic activity. As in theory, there are also two strands of the empirical literature on the macroeconomic effects of government spending shocks. The first one relies on structural VAR models to analyze national or international data. In order to identify the government spending shocks, one requires to make certain assumptions regarding the use of time lags and additional information such as various elasticities (Blanchard and Perotti, 2002; Perotti, 2005; and Giordano et al., 2007). While it has the advantage of easy implementation and application, the results are highly sensitive to these assumptions. Moreover, as Ramey (2011a) points out, the fiscal shocks identified with this method could be subject to an 'anticipation effect', whereby the shocks identified by the model are expected by the private sector. Because of this criticism, the second, so called 'narrative', approach seeks to identify shocks to government spending by using events associated with unexpected changes in government expenditure. In particular, military build-ups (sometimes combined with contemporaneous professional forecasts of government spending) were suggested as sources of such exogenous variation in government spending (Ramey and Shapiro, 1998; Burnside et al., 2004; Ramey, 2011a; and Barro and Redlick, 2011). It is argued that wars and international tensions lead to military build-ups that are both sufficiently difficult to predict and independent of GDP to be used as instruments to capture unanticipated fiscal shocks. Importantly, the estimates of the fiscal multiplier obtained using this approach are considerably lower than those obtained with the VAR methodology: around or below unity, suggesting that fiscal stimuli have little positive economic effect.

In Section 2, we provide a critical reassessment of the military build-ups instrument 
widely used in the narrative approach, and discuss the value of the multiplier. In Section 3, we demonstrate empirically the weaknesses of relying on military build-ups as instruments for increases in defense spending. We stress that this approach has two important downsides: the composition of government expenditure associated with military build ups is significantly different from the general government spending, and increases in federal military spending tend to be accompanied by concurrent decreases in non-defense and local government spending.Finally, Section 4 concludes.

\section{Are military build-ups an appropriate instrument?}

In this paper, we argue that the use of military build-ups as an instrument for fiscal shocks has some important limitations. First, although military build-ups are typically characterized as an exogenous instrument to capture fiscal policy, in actual fact they are hardly exogenous. Often, wars and military build-ups are expected several weeks or months before they actually break out. For example, the breaking out of hostilities between the US and Japan during the World War II was widely expected. What was unexpected was the direction of the initial Japanese attack: the US military anticipated the first strike to be directed against the Philippines rather than Hawaii. Other conflicts, such as the Vietnam War or the two Gulf Wars, were also preceded by long periods of tensions and escalations. Such expectations can affect private economic activities significantly, and also bring about some vital policy adjustments, which we highlight below.

Second, military conflicts, even when they are extra-territorial (as in the case of the US), do have significant contemporaneous effects on the domestic economy. Large numbers of young men are conscripted into the armed forces: for example, the number of draftees was 10.1 million (19.1\% of the labor force) during World War II, 1.5 million (2.4\%) during the Korean War, and 1.9 million (2.4\%) during the Vietnam War. The drafting of large numbers of prime-age men affected the economy in at least two important ways: it removed the men from the labor force, and it induced large numbers of women to become economically active (see, for example, Acemoglu, Autor and Lyle, 2004, and the references therein). Both effects are likely to have affected US households profoundly, during each war and also after its conclusion: due to military casualties among men and permanently increased labor-force participation of women. Additional effects of military build-ups and wars include firms switching their output towards military-use products, physical assets originally designed for 
civilian-use (such as trucks, boats and planes) being redirected for military uses such as transporting troops or ordnance, and rationing and price controls (implemented in the US during World War II for a range of goods).

Third, the identification strategy in this kind of exercise relies on relatively infrequent and unusual events. As shown in the next section, the effects of military build-ups in the US are much different depending on which events, such as World War II and the Korean War,.are included.

Fourth, the applicability of this approach is largely limited to the US, which is in a rather unique position in that it was involved in several military conflicts (hot or cold) that did not unfold on its territory. The same can be said about few other countries: either they were not involved in military conflicts, or these took place (at least in part) on their own territory. This makes the replication of such studies for most other countries rather difficult.

Finally, the composition of military spending differs considerably from general government spending. Therefore, estimating the macroeconomic effect of military build-ups may have limited applicability to other categories of government spending.

The effect of government spending on the economy is often summarized by a multiplier: a change of output caused by a one-unit increase in government spending. As Barro and Redlick (2011) suggest, the multiplier based on military build-ups corresponds only to the defense spending multiplier. To assess the effect of more typical fiscal stimulus packages, we are interested in the multiplier for non-defense spending such as the spending on infrastructure, health, education and other categories. However, a big hurdle in obtaining estimates of the non-defense spending multiplier is that it is hard to find a satisfactory instrument for nondefense spending because most of the variation in nondefense spending tends to be endogenous with respect to the state of economy.

Numerous studies have attempted to estimate the value of the government spending multiplier. Some of this research focuses on the non-defense spending multiplier in the US based on the narrative approach, using instruments other than military build-ups. For instance, Serrato and Wingender (2010) use changes in the allocations of federal spending to states caused by population changes identified by means of the Census every 10 years. Their estimates imply that government spending has a local income multiplier of 1.88. Shoag (2010), in turn, collects a new dataset on the returns of state pension plans, which can be a 
predictor of subsequent state government spending. He shows that state government spending has a large positive effect on in-state income with a multiplier of 2.11. Fishback and Kachanovskaya (2010) use political competiveness across states to estimate the effects of New Deal spending and find a multiplier of 1.7. In addition, the Congressional Budget Office (2010) calculates the non-defense spending multiplier (1.0 to 2.5) from large macro-economic models. In contrast, the multipliers obtained with military build-ups tend to be lower, ranging from 0.6 to 1.2 (Ramey, 2011; Barro and Redlick, 2011), so it appears that the defense and non-defense spending multipliers are, indeed, different from each other. It may also be noted that without distinguishing between defense and non-defense based multipliers, Blanchard and Perotti (2002) calculate the value of the multiplier as somewhere between 0.9 and 1.29, while Moutford and Uhlig (2009) find it to be 0.65. See Ramey (2011b) for a comprehensive list of papers on the government spending multiplier and the associated multiplier values.

\section{Revisiting the use of military build-ups as instrument for fiscal shocks}

The narrative approach to analyzing the economic effects of fiscal shocks relies on using military build-ups resulting from wars or military confrontations to identify exogenous fiscal shocks. ${ }^{1}$ Ramey (2011a) shows that the defense news captures the expectations of future government spending shocks by the private agents in the US. Figure 1 shows the trend of defense and nondefense spending of the federal government, and state and local governments, expressed as a ratio to real GDP. Defense spending is a major part of both total spending and federal government spending. Moreover, the fluctuations of federal government spending almost perfectly match that of defense spending. This is the reason why much of the literature chooses military build-ups as an instrument for capturing government spending shocks.

Barro and Redlick (2011) highlight a particular problem associated with using military build-ups to study the effects of government spending shocks. The nature of government spending during a military build-up differs dramatically from general government expenditures. Barro and Redlick (2011) point out that although military build-ups provide an excellent opportunity to estimate the multiplier, this is in fact only the multiplier for defense

1. While Ramey and Shapiro (1998) use the Korean War, Vietnam War and the Soviet invasion of Afghanistan, Ramey (2011a) adds also World War II and 9/11. 
expenditure, not a multiplier for total government expenditure. Yet, Ramey (2011a) estimates the government spending multiplier and analyzes transmission of spending shocks using military build-ups as if they were general government spending shocks.

To see how the results change depending on the definition of government spending, we replicate the analysis of Ramey (2011a) with data covering the period from 1939 to 2008. Figure 2 shows the impulse responses to a shock in the defense news variables. Solid lines show the impulse responses when defense spending is used instead of total government spending, and dashed lines show the results using total government spending. ${ }^{2}$ The two impulse responses are very similar. This result is not surprising, considering that the data include the two exceptionally large wars: World War II and the Korean War, and given that defense spending accounts for the bulk of government spending.

Turning to the potentially important issue of the Ramey (2011a) results being dominated by two extraordinarily large events,. it is interesting to note that when these events are excluded by considering only the data after 1955, the ratio of defense spending to GDP displays relatively little variation. Table 1 shows that during World War II and the Korean War, defense spending accounted for most of the variation in government spending because its ratio to total government spending is much higher than in other periods. Indeed, Ramey (2011a) observes that military build-ups have explanatory power only when these two large wars are included; military build-ups after the Korean War have very low explanatory power and are not informative. Therefore, since World War II and the Korean War dwarf all other military build-ups, this instrument may be viewed as based on only two events. We further probe this by analyzing the period from 1975 to 2008, excluding also the Vietnam War. Figure 3 shows the effects of the defense news on the key variables in this case. The government spending increases only on impact and then falls for 5 years, although it is not significant at conventional levels. The response of GDP is similar to that obtained by Ramey (2011a) when excluding the two large events. Finally, Ramey (2011a) also uses professional forecasts instead of the defense news shocks for a period from 1968 to 2008 and obtains results similar to those for 1955 to 2008 with defense news shocks. Therefore, Ramey’s (2011a) hump-shaped responses of government spending and GDP appear driven by World War II and the Korean War.

2. Total government spending consists of defense and nondefense spending of the federal government, and the spending of state and local governments. 
In addition, Ramey and Shapiro (1998) argue that military build-ups have the advantage that they do not remove private resources except in the manufacturing sector. Ramey (2011a) explains that the military spending was financed mostly by issuing debt during World War II and by taxes during the Korean War. However, it is possible that the increase in defense spending is financed in part by decreasing the allocations to other components of government spending, such as nondefense and state/local spending. That would imply that military buildups cause a transfer of resources within the government sectors. As much of the literature, such as Ilzetzki et al. (2011) and Bénétrix and Lane (2009) shows, the macroeconomic effects of government spending depend on its function. ${ }^{3}$ Therefore, when using military build-ups which are concentrated in the defense sector, it is necessary to account for the changes in the remaining sectors of government spending by including them among the endogenous variables.

We, therefore, again apply Ramey’s (2011a) specification, data and methodology based on defense news, with the three sectors of total government spending (defense, non-defense and state/local) also included. Figure 4 shows the results. The impulse response of defense spending closely resembles Ramey's results with a hump-shaped pattern. However, we observe large and significant falls in nondefense and state/local spending: the increased defense spending crowds out the spending in the other two sectors. This analysis sheds light on the effects of military builds-ups on the total government spending: the increase in defense spending is partly counterbalanced by decreases in the remaining sectors. The resulting macroeconomic effects reflect these compositional responses of government spending sectors. The resulting multiplier can appear lower than the general government spending multiplier because of the decreases of spending in the other two sectors. Following Ramey (2011a), the implied elasticity of peak GDP to defense spending is 0.047 and the average ratio of GDP to defense spending is 15.2 from 1947 to 2008. The implied defense spending multiplier then is $0.7,{ }^{4}$ which is similar to the defense spending multiplier range $(0.6 \sim 0.9)$ found by Barro and Redlick (2011) and the range (0.6 0.8) of Ramey (2011a) for the same period. Since this multiplier is calculated by including the effects of crowding out in other government sectors, the pure defense spending multiplier should be higher than this.

3. According to Bénétrix and Lane (2009), the effects of government spending shocks are different according to the nature of fiscal innovation: shocks to government consumption and shocks to government investment, and the latter has a positive and larger fiscal multiplier.

4 When we use the average ratio (5.0) of GDP to the total government spending for the same period, the implied defense spending multiplier is 0.23 . 
In Figure 4, we show the responses of other variables such as GDP, real wage and consumption. We do this as it enables us to compare the outcomes with the predictions of the neoclassical and new Keynesian models. In the neoclassical model, a fiscal stimulus translates into a negative wealth effect. The increased public spending needs to be financed by higher taxes, either in the present or in the future. Households, therefore, reduce their consumption to save more, and increase their labor supply which results in falling wages. In the new Keynesian model, by contrast, the fiscal stimulus boosts aggregate demand and the demand for labor, so that both consumption and wages rise. Both views thus predict rising output, either because of increased labor input or because of the aggregate demand effect. However, the responses of private consumption and wages predicted by the two models are in opposite directions.

In our empirical exercise, we find responses that are qualitatively similar to those of Ramey and Shapiro (1998) and Ramey (2011a) to an extent, but one can also detect other patterns. Defense spending rises up to the $4^{\text {th }}$ quarter, peaks in the $5^{\text {th }}$ quarter, stabilizes and then the increase continues at a declining rate. Non-defense spending falls sharply and stays low for five quarters, then starts rebounding slowly but stays negative. State and local spending falls till the $6^{\text {th }}$ quarter and then rebounds gradually. This shows quite clearly that there is crowding out of non-defense as well as state and local spending by defense spending. GDP rises till the $7^{\text {th }}$ quarter and then falls. The decline of the real wage till about the $7^{\text {th }}$ quarter is along the lines of the neoclassical theory, although it subsequently rises. Private consumption falls from the $3^{\text {rd }}$ quarter (neoclassical effect), but this trend is counteracted by an initial increase between the $1^{\text {st }}$ and $2^{\text {nd }}$ quarters, which is consistent with the new Keynesian standpoint. Although these are impulse responses to shocks and so the effects need not be permanent, the outcomes as depicted in the figures nevertheless point to some validation of both strands of arguments.

\section{Conclusion}

This paper offers a reassessment of the use of military build-ups as instruments for identifying fiscal shocks. We argue that this approach suffers from two important drawbacks. First, the defense spending associated with military build-ups is different in nature and scope from the general government expenditure. Therefore, the estimated effects capture the response of the economy to defense spending and cannot be readily applied to increases in 
other types of government expenditure, such as during the recent stimulus programs. Likewise, the resulting multiplier can be interpreted only as the defense spending multiplier and not the general fiscal multiplier. Second, as our empirical analysis demonstrates, increases in the US defense spending during military build-ups crowd out other types of government expenditure: both federal non-defense spending and expenditure by state and local governments fall after a defense spending shock. The estimated multiplier reflects these compositional changes and, as such, it is likely to underestimate the true response to government spending shocks. Both of these properties can help explain why narrative studies based on military build-ups tend to find a much lower fiscal multiplier than other studies.

These two weaknesses, along with the observation that wars and military build-ups, even if motivated by extraterritorial conflicts, are likely to have important direct effects on the labor force and private consumption, should cast doubt on the use of military build-ups as narrative instrument for estimating macroeconomic effects of fiscal shocks. This is not to say that the narrative approach itself should be discounted altogether. Rather, it may be worth looking for other more appropriate instruments to capture the effects of fiscal shocks.

\section{References}

Acemoglu, D., Autor, D.H. and Lyle, D. (2004). "Women, war and wages: The effect of female labor supply on the wage structure at midcentury." Journal of Political Economy 112 (3), 497-551.

Barro, R., and Redlick, C. (2011), "Macroeconomic effects from government purchases and taxes”, Quarterly Journal of Economics, 126, 51-102.

Bénétrix, A., and Lane, P. (2009), “The impact of fiscal shocks on the Irish economy”, Economic and Social Review, 40, 407-434.

Blanchard, O., and Perotti, R. (2002), “An empirical characterization of the dynamic effects of changes in government spending and taxes on output”, Quarterly Journal of Economics, 119, 1329-1368.

Burnside, C., Eichenbaum, M. and Fisher, Jonas D.M. (2004), "Fiscal shocks and their consequence”, Journal of Economic Theory, 115, 89-117.

Congressional Budget Office (2010), “Estimated impact of the American recovery and reinvestment act on employment and economic output from October 2009 through December 2009”, CBO report 4136.

Fishback, Price V., and Kachanovskaya, V. (2010), "In search of the multiplier for federal spending in the states during the new deal”, NBER working paper, 16561.

Giordano, R., Momigliano, S., Neri, S., and Perotti, R. (2007), "The effects of fiscal policy in Italy: Evidence from a VAR model”, European Journal of Political Economy, 23, 707-733.

Ilzetzki, E., Mendoza, E. G., and Végh, C. A. (2011), "How big (small?) are fiscal 
multipliers?”, IMF working paper 11/52.

Mountford, A., and Uhlig, H. (2009), "What Are The Effects of Fiscal Policy Shocks?”,Journal of Applied Econometrics, 24, 960-992.

Perotti, R. (2005), "Estimating the effects of fiscal policy in OECD countries", CEPR discussion paper, 4842.

Serrato, Juan C. S., and Wingender, P. (2010), “Estimating local fiscal multipliers”, Berkeley working paper, November.

Shoag, Daniel (2010), “The impact of government spending shocks: Evidence on the multiplier from state pension plan returns”, Job Market Paper.

Ramey, V. A. (2011a), "Identifying government spending shocks: it's all in the timing”, Quarterly Journal of Economics, 126, 1-50.

Ramey, V. A. (2011b) “Can Government purchases stimulate the economy?”, Journal of Economic Literature, 49, 673-685.

Ramey, V. A., and Shapiro, M. D. (1998), "Costly Capital Reallocation and the Effects of Government Spending”, Carnegie-Rochester Conference Series on Public Policy, 48, 145194. 
Table 1 Average ratio of defense spending to government spending

\begin{tabular}{|l|c|c|c|c|}
\hline \multicolumn{1}{|c|}{ Period } & 1929 2011 & $1955 \sim 2011$ & $1941 \sim 1946$ & $1951 \sim 1956$ \\
\hline \hline Defense/Total government & 0.39 & 0.33 & 0.78 & 0.58 \\
\hline Defense/Federal spending & 0.70 & 0.73 & 0.92 & 0.87 \\
\hline
\end{tabular}

Figure 1 Components of real government spending fraction of GDP (chained 2005 dollars)

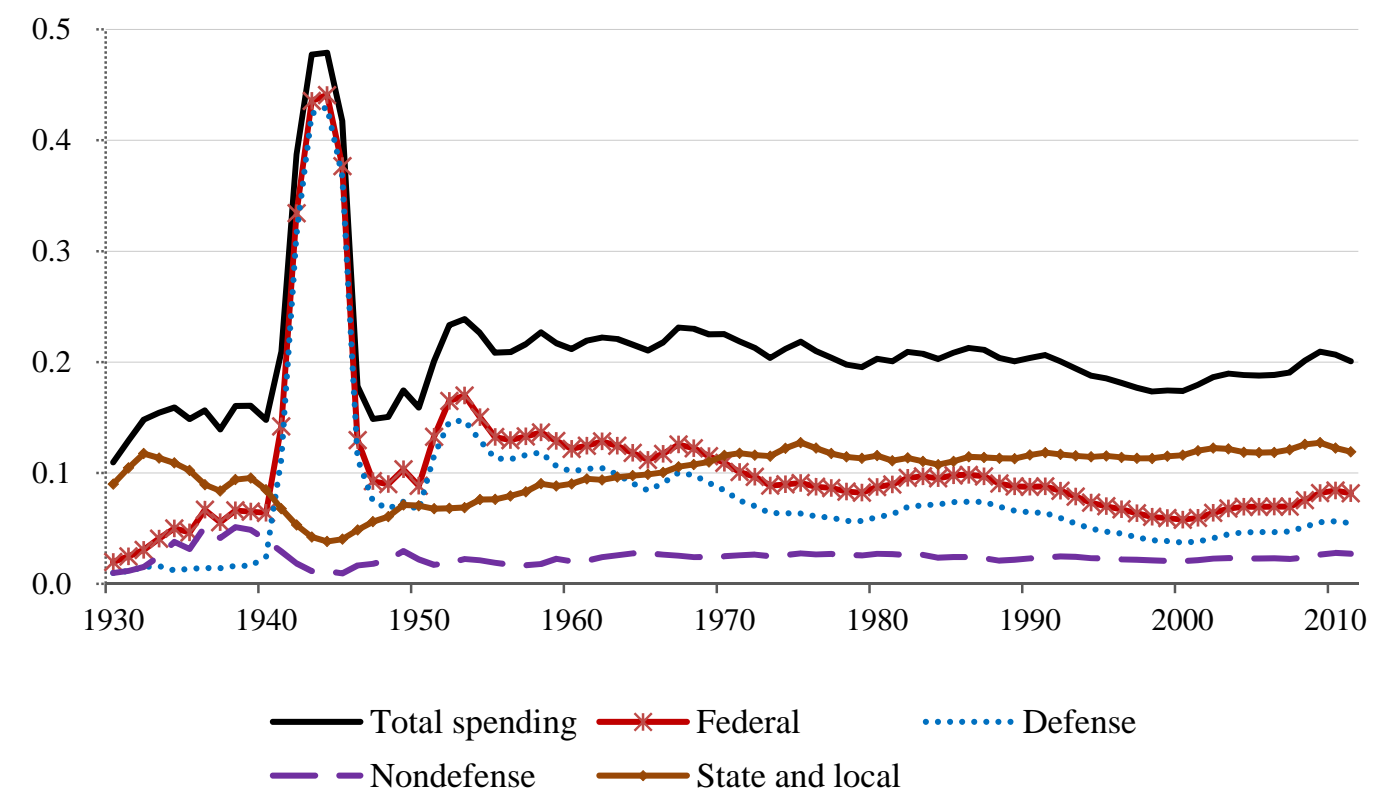


Figure 2 The effects of defense spending and government spending (1939 2008)

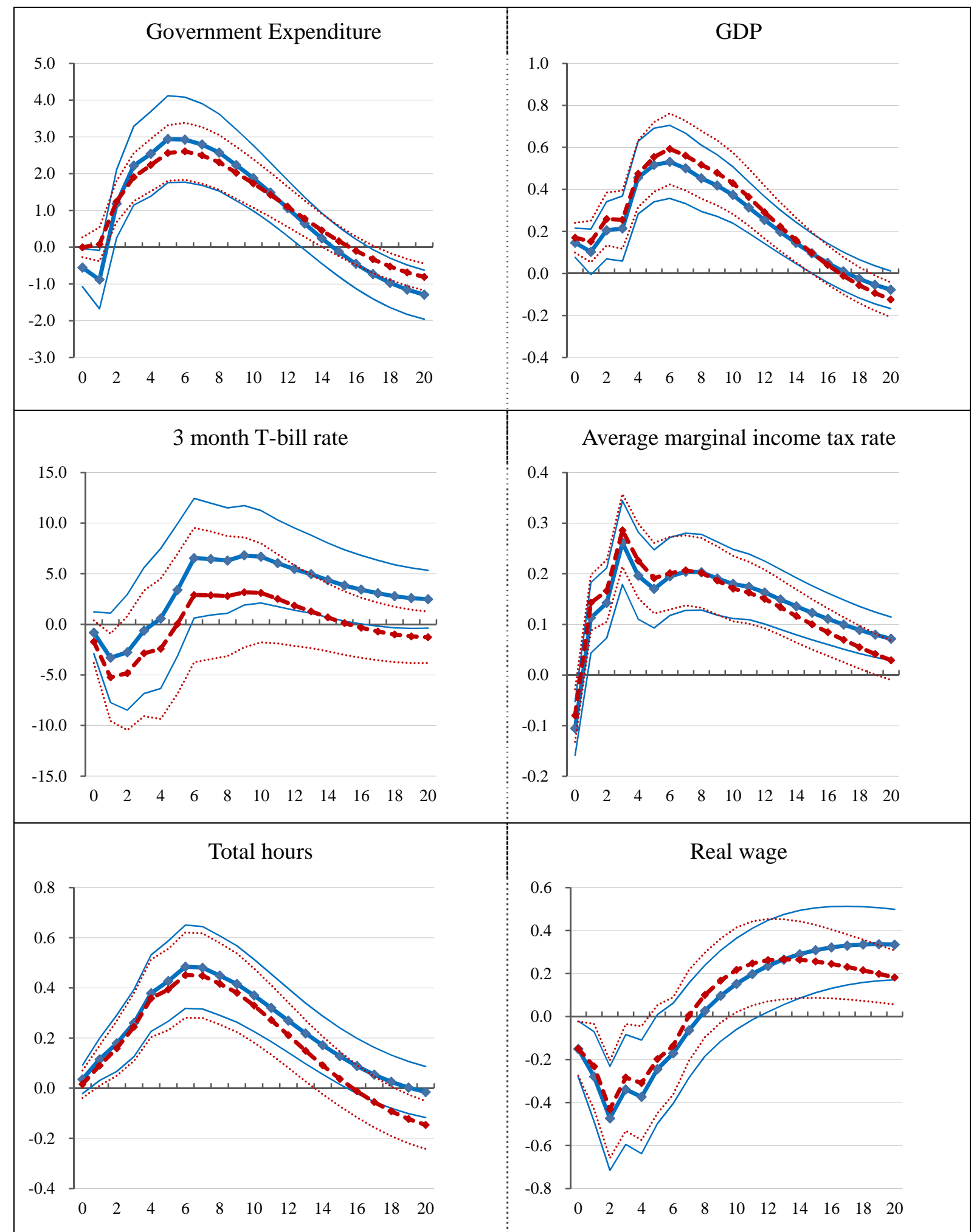

Notes: The solid lines show the responses with $68 \%$ confidence interval bands following Ramey's (2011a) specification with defense spending instead of total government spending. The dashed lines show the results of Ramey's specification with total government spending. 
Figure 3 The effects of defense news shocks from 1975 to 2008

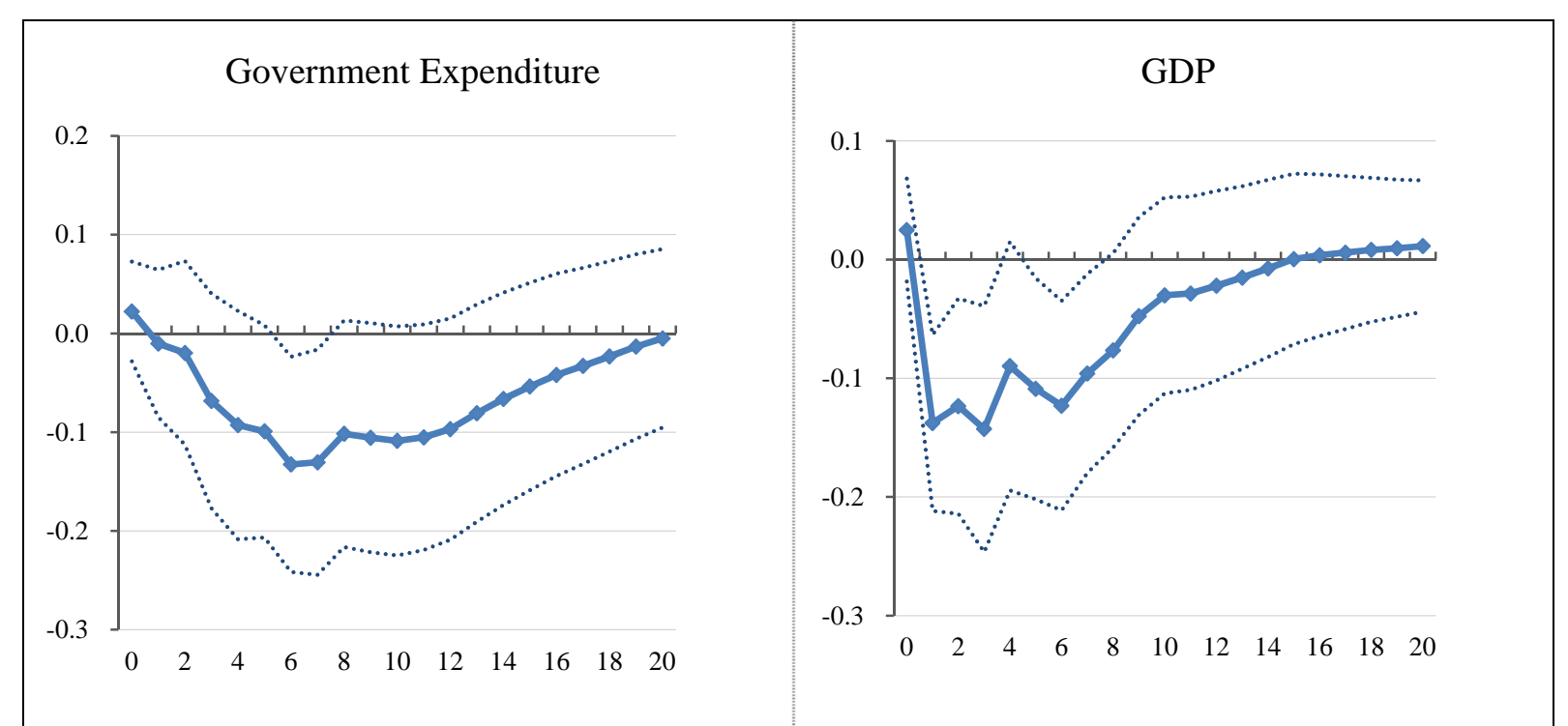

Note: The solid lines display point estimates while the dashed lines correspond to $68 \%$ confidence interval bands. 
Figure 4 The effects of defense spending shocks from 1947 to 2008

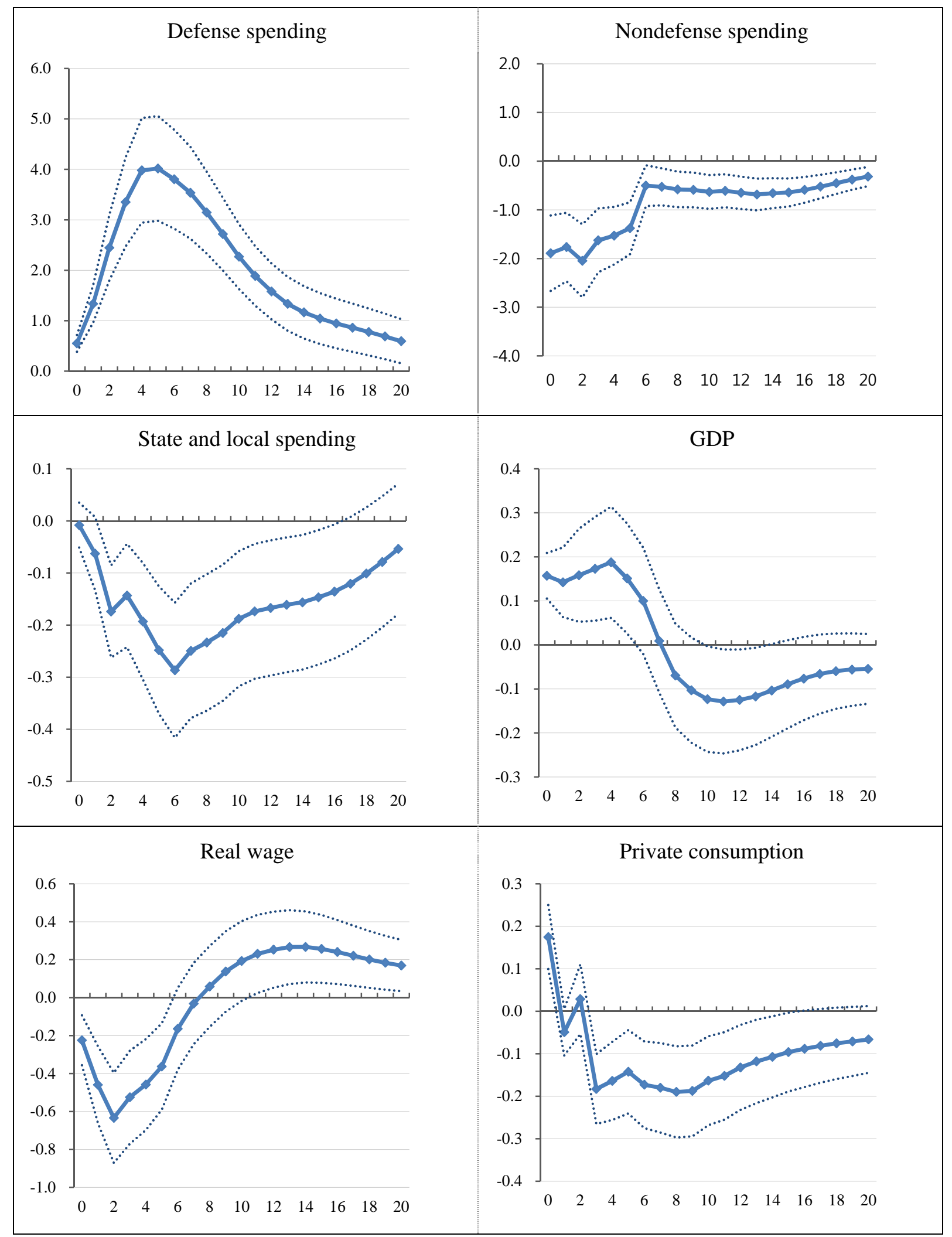

Note: The solid lines display point estimates while the dashed lines correspond to $68 \%$ confidence interval bands 